\title{
Psychosocial, behavioral and clinical correlates of children with overweight and obesity
}

\author{
Vidhu V. Thaker ${ }^{1 *}$ (D), Stavroula K. Osganian², Sarah D. deFerranti ${ }^{3,4}$, Kendrin R. Sonneville ${ }^{5}$, Jennifer K. Cheng ${ }^{4,6}$,
} Henry A. Feldman ${ }^{7}$ and Tracy K. Richmond ${ }^{4,8}$

\begin{abstract}
Background: Psychological and behavioral correlates are considered important in the development and persistence of obesity in both adults and youth. This study aimed to identify such features in youth with severe obesity (BMI $\geq 120 \%$ of $95^{\text {th }}$ percentile of sex-specific BMI-for-age) compared to those with overweight or non-severe obesity.

Methods: Youth with $\mathrm{BMI} \geq 85^{\text {th }}$ percentile were invited to participate in a prospective research registry where data was collected on attributes such as family characteristics, eating behaviors, dietary intake, physical activity, perception of health and mental well-being, and cardiometabolic parameters.

Results: In a racially/ethnically diverse cohort of 105 youth (65\% female, median age 16.1 years, range 4.62-25.5), 51\% had severe obesity. The body fat percent increased with the higher levels of obesity. There were no differences in the self-reported frequency of intake of sugar sweetened beverages or fresh produce across the weight categories. However, the participants with severe obesity reported higher levels of emotional eating and eating when bored $(p=$ 0.022 ), levels of stress $(p=0.013)$, engaged in fewer sports or organized activities $(p=0.044)$, and had suboptimal perception of health $(p=0.053)$. Asthma, depression and obstructive sleep apnea were more frequently reported in youth with severe obesity. The presence of abnormal HDL-C, HOMA-IR, hs-CRP and multiple cardiometabolic risk factors were more common among youth with severe obesity.
\end{abstract}

Conclusions: Youth with severe obesity have identifiable differences in psychosocial and behavioral attributes that can be used to develop targeted intervention strategies to improve their health.

Keywords: Childhood obesity, Psychosocial, Behavioral

\section{Background}

Obesity and severe obesity are prevalent in the United States and the rates continue to rise among children. Recent data from NHANES indicates that 18.5\% [15.8-21.3] of youth ages 2-19 years have obesity, defined as body mass index $(B M I) \geq 95^{\text {th }}$ percentile of a sex-specific BMI-

\footnotetext{
* Correspondence: vvt2114@cumc.columbia.edu

'Division of Molecular Genetics, Department of Pediatrics, Columbia University Irving Medical Center, 1150, St. Nicholas Avenue, New York, NY 10032, USA

Full list of author information is available at the end of the article
}

for-age, and 5.6\% [4.0-7.6] have severe obesity, defined as BMI $\geq 120 \%$ of $95^{\text {th }}$ percentile of sex-specific BMI-for-age. Severe obesity increased from $4.0 \%$ in $1999-2000$ to $6.0 \%$ in 2015-16 and the highest prevalence is seen among adolescents ages $12-19$ years at $7.7 \%$ [5.0-11.2] [1, 2]. Severe obesity is disproportionately higher among minorities (Hispanics and Non-Hispanic Blacks), youth living in nonurban areas, and households headed by individuals with high school education or less [3].

Children and adolescents with severe obesity are at higher risk for abnormal cardiovascular risk factors

(c) The Author(s). 2020 Open Access This article is licensed under a Creative Commons Attribution 4.0 International License, which permits use, sharing, adaptation, distribution and reproduction in any medium or format, as long as you give appropriate credit to the original author(s) and the source, provide a link to the Creative Commons licence, and indicate if changes were made. The images or other third party material in this article are included in the article's Creative Commons licence, unless indicated otherwise in a credit line to the material. If material is not included in the article's Creative Commons licence and your intended use is not permitted by statutory regulation or exceeds the permitted use, you will need to obtain permission directly from the copyright holder. To view a copy of this licence, visit http://creativecommons.org/licenses/by/4.0/ The Creative Commons Public Domain Dedication waiver (http://creativecommons.org/publicdomain/zero/1.0/) applies to the data made available in this article, unless otherwise stated in a credit line to the data. 
including higher blood pressure, lipids, insulin resistance and diabetes [4-6]. Additionally, they are more likely to experience asthma [7], depression, anxiety, and poor psychological well-being [8]. There is a critical need to identify behaviorally-based interventions that will maximize health of youth with severe obesity [9-11]. Yet, few studies have identified psychosocial and behavioral factors for severe obesity [12] that could inform such strategies. This study aimed to examine the psychosocial, behavioral, and clinical correlates of severe obesity in a cohort of youth to identify the contextual and behavioral factors that differentiate those with severe obesity compared to those with nonsevere obesity and overweight.

\section{Methods}

The POOL registry cohort, named for the various participating clinics, was a prospective and voluntary registry for youth with overweight and obesity, ages 225 years old recruited from weight management and primary care clinics at Boston Children's Hospital $(\mathrm{BCH})$ from 2012 to 2016. The eligibility criteria were a) BMI $\geq$ $85^{\text {th }}$ percentile of a sex-specific BMI-for-age for those < 18 years on CDC 2000 growth charts or $\geq 25 \mathrm{~kg} / \mathrm{m}^{2}$ for those $\geq 18$ years; b) English speaking; and c) residents of New England as determined by the zip code of residence. Patients intending to undergo bariatric surgery for weight loss underwent the baseline visit prior to the surgery. Exclusion criteria were a) significant cognitive, psychosocial or medical illness that limits the subject's ability to provide assent and/or participate in the research procedures such as severe autism, developmental delay and/or other conditions as determined by the investigators and b) pregnancy or intention to become pregnant within the next year for females. Patients were recruited by flyers posted in the clinics, by mail, or during a clinical visit. The study protocol was approved by the Institutional Review Board at $\mathrm{BCH}$.

\section{Measures}

Study visits were conducted in the Clinical and Translational Study Unit (CTSU) after an overnight fast. An average of two measurements of height (nearest $0.1 \mathrm{~cm}$ ) and weight (nearest $0.1 \mathrm{~kg}$ ) obtained using a fixed stadiometer and Tanita digital scale, respectively with no shoes worn and outer clothing removed were obtained. The BOD POD Gold Standard Body Composition Tracking System (COSMED, the Metabolic Company, Rome, Italy), an air displacement plethysmograph (ADP) method that measures whole body densitometry was used to determine fat and fat free mass [13, 14]. Three measurements of blood pressure were taken by auscultation in the seated position on the right arm after $3 \mathrm{~min}$ rest, and the average of the final two measurements was used. Physicians conducted Tanner staging by physical examination on participants ages 6 to 18 years [15]. Tanner stage 1 was considered prepubertal, and all others post-pubertal. Children $<6$ years were assumed to be prepubertal and those $>18$ years post-pubertal.

Parents of participants $\leq 12$ years and older participants completed a) sociodemographic questionnaire with questions on race, ethnicity, and education, b) family history, c) medical history of conditions that were diagnosed by a health care provider including mental health diagnoses such as depression, anxiety, and ADHD, and d) questions adapted from the Youth Risk Behavior Questionnaire on diet, physical activity, sedentary behaviors, and attitudes about health [16]. A 10-point Likert scale question was used to assess the level of stress experienced by the youth in the past year where 1 means 'no stress' and 10 means 'extreme amount of stress'. Pediatric Quality of Life Inventory (PedsQL) was used to measure health-related quality of life (HRQOL). The PedsQL has developmentally appropriate modules that assess 4 generic core scales (Physical, Emotional, Social, and Work or School functioning). Scores were calculated for each scale as well as for psychosocial health, which is an average of the emotional, social and work/school functioning scores. The overall health is the average of physical and psychosocial health scores. Parents completed the parent proxy age specific modules for participants $\leq 12$ years; whereas, older participants completed the age-specific self-report modules [17, 18]. Participants $\geq 13$ years completed items on the Three-Factor Eating Questionnaire (TFEQ-R18) to measure 3 aspects of eating behavior including cognitive restraint (CR), uncontrolled eating (UE), and emotional eating (EE) [19] and selected items from McKnight Risk Factor Survey to assess disordered eating, which included the following questions: "In the past 12 months, how often have you kept eating and eating and felt like you could not stop?" and "In the past 12 months, how often did you eat more than usual when you were bored or upset?" [20].

\section{Lab assay methods}

Fasting blood samples were obtained for lipids, insulin, glucose and hs-CRP and tested within 24 hours. The tests assays were performed on Roche/Hitachi Cobas ${ }^{\circ} \mathrm{c}$ system analyzer using the following methods: 1 ) Triglycerides: lipoprotein lipase enzymatic test (CV range $0.7-$ $2.0 \%)$; 2) High-density lipoprotein (HDL-C) and Total Cholesterol (TC): enzymatic colorimetric method (CV range: HDL-C: $0.5-1.5 \%$; TC: $0.6-1.6 \%)$; 3) Low-density lipoprotein (LDL-C) cholesterol: Friedewald calculation $(\mathrm{TC}=\mathrm{HDL}-\mathrm{C}+\mathrm{LDL}-\mathrm{C}+\mathrm{VLDL}-\mathrm{C}$ where VLDL-C is defined as TG/5 in the fasting state); 4) Glucose: hexokinase enzymatic test (CV range $0.5-1.3 \%)$; 5) Insulin: electrochemiluminescence Immunoassay (ECLIA, CV 
range 1.1-4.9\%); 6) hs-CRP: particle-enhanced immunological agglutination assay (CV range $0.6-3.5 \%$ ).

\section{Analysis methods}

All analyses are cross-sectional. BMI was calculated as weight $/$ height ${ }^{2}\left(\mathrm{~kg} / \mathrm{m}^{2}\right)$. The definition of clinical and laboratory parameters used in the study is noted in Table 1. Descriptive statistics were calculated as the median and range for continuous variables and as proportions for categorical variables. Correlation between continuous measures was assessed using the Spearman coefficient. Proportions were compared among weight categories by Fisher's exact test. Due to skewness, distributions of continuous variables were compared among the weight categories using the Jonckheere-Terpstra Test for Independent Samples. An analysis of co-variance (ANCOVA) was conducted to control for age and sex when comparing metabolic risk factor variables across weight categories. Log-transformation was performed for variables with significant departure from normality. A two -sided $p$ value $<0.05$ was considered statistically significant. All analyses were conducted with IBM SPSS Statistics for Windows, Version 23.0 (IBM Corp, Armonk, NY).

\section{Results}

A total of 803 potentially eligible children were identified from the 7 clinics and 681 were screened and eligible, of which 387 declined to participate; 102 could not be contacted again; 192 were eligible and agreed to participate; and 105 met all eligibility criteria and completed the baseline visit. Characteristics of the 105 children who participated in the baseline assessment are shown in Table 2. Median age of participants was 16.1 years $(65 \%$ females); participants were of diverse racial and ethnic backgrounds. About half the sample (51.4\%) had severe obesity, while $29.5 \%$ had non-severe obesity, and $19.1 \%$ had overweight. There were no statistically significant differences in the sociodemographic variables by category of weight. Median BMI of the participants was $31.7 \mathrm{~kg} / \mathrm{m}^{2}$ (range 18.1-63.6) and median total body fat of $37.6 \%$ (range 12.2-61.0). Median total body fat increased significantly across the weight categories, and correlated strongly with BMI $(\mathrm{r}=0.76 ; p=<0.001)$. About half of participants were post-pubertal across each of the weight categories. There was a strong family history of obesity, with $75 \%$ of the participants reporting maternal obesity. Participants with severe obesity had a number of comorbid conditions, with asthma (26.7\%)

Table 1 Definitions of cohort measurement parameters

\begin{tabular}{|c|c|c|c|}
\hline & Description & & Reference \\
\hline Weight categories & Age $<18$ years & Age $\geq 18$ years & \multirow{5}{*}{$\begin{array}{l}\text { CDC } 2000 \text { growth curves; Gulati 2012; } \\
\text { Skinner 2015; Skinner } 2016\end{array}$} \\
\hline Overweight & BMI $85-95^{\text {th }}$ percentile & BMI $25-30 \mathrm{~kg} / \mathrm{m}^{2}$ & \\
\hline Class 1 obesity & BMI $95-120 \%$ of $95^{\text {th }}$ percentile & BMI $30-35$ kg/m² & \\
\hline Class 2 obesity & BMI $120-140 \%$ of $95^{\text {th }}$ percentile & BMI $35-40 \mathrm{~kg} / \mathrm{m}^{2}$ & \\
\hline Class 3 obesity & $\mathrm{BMI}>140 \%$ of $95^{\text {th }}$ percentile & $\mathrm{BMI}>40 \mathrm{~kg} / \mathrm{m}^{2}$ & \\
\hline Laboratory parameters & \multicolumn{2}{|l|}{ Definition of Abnormal } & \\
\hline Fasting blood glucose & $\geq 126 \mathrm{mg} / \mathrm{dL}$ & All ages & ADA diabetes care guidelines 2018 \\
\hline Fasting insulin & $>12 \mathrm{ulU} / \mathrm{mL}$ & All ages & \multirow[t]{2}{*}{ Laboratory reference range } \\
\hline HOMA-IR & $\geq 3$ units & All ages & \\
\hline C-reactive protein & $\geq 3 \mathrm{mg} / \mathrm{dL}$ & All ages & $\begin{array}{l}\text { Framingham Heart Study CHD Risk } \\
\text { Scores; Jialal 2004; Buckley } 2009\end{array}$ \\
\hline LDL & $\geq 110 \mathrm{mg} / \mathrm{dL}$ & $\geq 120 \mathrm{mg} / \mathrm{dL}$ & \multirow{6}{*}{$\begin{array}{l}\text { NHLBI Integrated Guidelines for Cardiovascular } \\
\text { Risk Reduction in Children and Adolescents } \\
\text { (Expert Panel, 2011) }\end{array}$} \\
\hline Total Cholesterol & $\geq 170 \mathrm{mg} / \mathrm{dL}$ & $\geq 190 \mathrm{mg} / \mathrm{dL}$ & \\
\hline $\mathrm{HDL}$ & $\leq 40 \mathrm{mg} / \mathrm{dL}$ & All ages & \\
\hline \multirow[t]{3}{*}{ Triglycerides } & $\geq 75 \mathrm{mg} / \mathrm{dL}$ & ages 2-9 years & \\
\hline & $\geq 90 \mathrm{mg} / \mathrm{dL}$ & ages $10-19$ years & \\
\hline & $\geq 115 \mathrm{mg} / \mathrm{dL}$ & ages $\geq 20$ years & \\
\hline \multirow[t]{2}{*}{ SBP } & $\geq 95^{\text {th }} \%$ tile for age, sex and height & ages $2-17$ years & \multirow{4}{*}{$\begin{array}{l}\text { Fourth Report on the Diagnosis, Evaluation, } \\
\text { and Treatment of High Blood Pressure in } \\
\text { Children and Adolescents (2004) } \\
\text { Seventh Report of the Joint National Committee } \\
\text { on the Prevention, Detection, Evaluation, and } \\
\text { Treatment of High Blood Pressure for adults (2003) }\end{array}$} \\
\hline & $\geq 140 \mathrm{mmHg}$ & ages $\geq 18$ years & \\
\hline \multirow[t]{2}{*}{ DBP } & $\geq 95^{\text {th }} \%$ tile for age, sex and height & ages $2-17$ years & \\
\hline & $\geq 90 \mathrm{mmHg}$ & ages $\geq 18$ years & \\
\hline Multiple risk factor variable & $\begin{array}{l}\text { Abnormal values for glucose, } \mathrm{LDL}, \mathrm{HDL} \text {, } \\
\mathrm{CRP} \text { or } \mathrm{BP} \text { or taking medications for } \\
\text { diabetes, dyslipidemia or hypertension }\end{array}$ & & \\
\hline
\end{tabular}


Table 2 Sociodemographic and clinical characteristics ofstudy participants overall and according to the weight category

\begin{tabular}{|c|c|c|c|c|c|c|}
\hline \multirow[t]{2}{*}{ Characteristic } & \multirow[t]{2}{*}{$n^{a}$} & \multirow[t]{2}{*}{ All } & \multicolumn{3}{|l|}{ Weight Category } & \multirow[b]{2}{*}{$p$-value ${ }^{* *}$} \\
\hline & & & Overweight & Obese & Severely Obese & \\
\hline Age; median (min, max) & 105 & $16.07(4.62,25.54)$ & $14.40(4.62,22.99)$ & $14.40(7.30,21.98)$ & $17.06(5.17,25.54)$ & 0.18 \\
\hline Age Group; $n(\%)$ & 105 & & & & & 0.42 \\
\hline Under 13 years & & $32(30.5 \%)$ & $6(30.0 \%)$ & $12(38.7 \%)$ & $14(25.9 \%)$ & \\
\hline 13 years or older & & $73(69.5 \%)$ & 14 (70.0\%) & $19(61.3 \%)$ & 40 (74.1\% & \\
\hline Gender; $n$ (\%) & 105 & & & & & 0.96 \\
\hline Male & & $41(39.0 \%)$ & $7(35.0 \%)$ & $12(38.7 \%)$ & $22(40.7 \%)$ & \\
\hline Female & & $64(69.0 \%)$ & $13(65.0 \%)$ & 19 (61.3\%) & $32(59.3 \%)$ & \\
\hline Race; $n(\%)$ & 100 & & & & & 0.52 \\
\hline Caucasian & & $34(34 \%)$ & $6(33.3 \%)$ & $12(41.4 \%)$ & $16(30.2 \%)$ & \\
\hline African-American & & $44(44 \%)$ & $6(33.3 \%)$ & $13(44.8 \%)$ & $25(47.2 \%)$ & \\
\hline Multiple Races/Other & & $22(22 \%)$ & $6(33.3 \%)$ & $4(13.8 \%)$ & $12(22.6 \%)$ & \\
\hline Ethnicity; $n$ (\%) & 102 & & & & & 0.58 \\
\hline Hispanic/Latino & & $22(21.6 \%)$ & $3(15.8 \%)$ & $5(16.7 \%)$ & $14(26.4 \%)$ & \\
\hline Not Hispanic/Latino & & $80(78.4 \%)$ & $16(84.2 \%)$ & $25(83.3 \%)$ & $39(73.6 \%)$ & \\
\hline Mother's Education; $n$ (\%) & 99 & & & & & 0.22 \\
\hline Some College or Less & & $60(60.6 \%)$ & $10(55.6 \%)$ & $15(50.0 \%)$ & $35(68.6 \%)$ & \\
\hline College Graduate or higher & & 39 (39.4\%) & $8(44.4 \%)$ & $15(50.0 \%)$ & $16(31.4 \%)$ & \\
\hline Father's Education; n (\%) & 76 & & & & & 0.08 \\
\hline Some College or Less & & $54(71.1 \%)$ & $7(46.7 \%)$ & $16(76.2 \%)$ & $31(77.5 \%)$ & \\
\hline College Graduate or Higher & & $22(28.9 \%)$ & $8(53.3 \%)$ & $5(23.8 \%)$ & $9(22.5 \%)$ & \\
\hline BMI, kg/m2; median (min, max) & 105 & $31.72(18.05,63.61)$ & $26.02(18.05,29.26)$ & $30.46(20.15,34.48)$ & $39.60(24.63,63.61)$ & $<0.001$ \\
\hline BMI z-score; median (min, max) & 105 & $2.18(1.14,3.78)$ & $1.39(1.14,1.62)$ & $1.91(1.59,2.24)$ & $2.49(2.04,3.78)$ & $<0.001$ \\
\hline$\%$ Total Body Fat & 105 & $37.60(12.2,61.0)$ & $31.75(12.20,42.90)$ & $35.60(20.90,43.30)$ & $45.60(20.40,61.00)$ & $<0.001$ \\
\hline Weight Categories; n (\%) & 105 & & & & & \\
\hline Overweight & & $20(19.1 \%)$ & & & & \\
\hline Obese & & $31(29.5 \%)$ & & & & \\
\hline Severely Obese & & $54(51.4 \%)$ & & & & \\
\hline Tanner Stage; $n(\%)$ & 99 & & & & & 0.20 \\
\hline Pre-pubertal & & $15(15.2 \%)$ & $2(10.5 \%)$ & $6(20.0 \%)$ & $7(14.0 \%)$ & \\
\hline Pubertal & & $29(29.3 \%)$ & $8(42.1 \%)$ & $11(36.7 \%)$ & $10(20.0 \%)$ & \\
\hline Post-pubertal & & $55(55.6 \%)$ & $9(47.4 \%)$ & $13(43.3 \%)$ & $33(66.0 \%)$ & \\
\hline \multicolumn{7}{|l|}{ Family History Obesity; $n$ (\%) } \\
\hline Mother & 84 & $63(75.0 \%)$ & $9(56.3 \%)$ & $16(76.2 \%)$ & $38(80.9 \%)$ & 0.19 \\
\hline Father & 69 & $30(43.5 \%)$ & $5(35.7 \%)$ & $7(41.2 \%)$ & $18(47.4 \%)$ & 0.80 \\
\hline Medical Diagnoses; $n$ (\%) & 105 & & & & & \\
\hline Asthma & & $28(26.7 \%)$ & $1(5.0 \%)$ & $6(19.4 \%)$ & $21(38.9 \%)$ & 0.007 \\
\hline High Cholesterol & & 19 (18.1\%) & $4(20.0 \%)$ & $8(25.8 \%)$ & 7 (13.0\%) & 0.33 \\
\hline Depression & & $17(16.2 \%)$ & $1(5.0 \%)$ & $2(6.5 \%)$ & $14(25.9 \%)$ & 0.02 \\
\hline Anxiety & & $13(12.4 \%)$ & $1(5.0 \%)$ & $5(16.1 \%)$ & $7(13.0 \%)$ & 0.58 \\
\hline ADHD & & $11(10.5 \%)$ & $1(5.0 \%)$ & $4(12.9 \%)$ & $6(11.1 \%)$ & 0.84 \\
\hline OSA & & $10(9.5 \%)$ & $0(0 \%)$ & $1(3.2 \%)$ & $9(16.7 \%)$ & 0.04 \\
\hline GE Reflux & & $10(9.5 \%)$ & $1(5.0 \%)$ & $1(3.2 \%)$ & $8(14.8 \%)$ & 0.20 \\
\hline
\end{tabular}

${ }^{a}$ number of participants after excluding missing or don't know/unknown responses for each variable

**P-values calculated from Fisher Exact Tests for categorical data or Jonckheere-Terpstra Test for Independent Samples for continuous data 
being the most common, followed by depression and obstructive sleep apnea, as compared to those with obesity or overweight. Amongst the less frequently self-reported conditions (data not shown), 1 participant had type 2 diabetes and 3 reported an eating disorder.

Among the dietary and eating behaviors, self-reported frequency of intake of specific food and drinks did not differ significantly across the weight categories (Table 3 ). However, among the subset of participants $\geq 13$ years, eating when bored was more frequently reported among those with obesity compared to those with overweight $(p=0.022)$. There was no significant difference in the eating behavior scores on the TEFQ-R18 for CR and UE by weight category; however, median scores for EE increased with increasing weight category (11.1 vs. 16.7 vs. 33.3 respectively, $p=0.026$ ). Subjects with severe obesity were more likely to report playing no sports or organized activities compared to those without $(47.2 \%$ vs. $35.5 \%$ vs. $15.8 \%$, respectively, $p=0.044$ ). Sedentary activities such as watching TV and video games or being active for $\geq 30$ $\mathrm{min} /$ day were similar across the weight categories.

The prevalence of abnormal levels of metabolic risk factors among all participants was high for lipids, hsCRP, HOMA-IR, and insulin, whereas it was low for blood pressure and glucose (Table 4). Statistically significant differences in the distributions of these risk factors by weight category were observed for the HDL-C, HOMA-IR, Insulin and hs-CRP. In this study, BMI showed no correlation with total cholesterol $(\mathrm{r}=-0.054$; $p=0.588)$, LDL-C $(\mathrm{r}=0.078 ; p=0.432)$ or triglycerides $(\mathrm{r}=0.161 ; p=0.102)$ but a moderate inverse correlation with HDL $(\mathrm{r}=-0.352 ; p<0.001)$. The greatest difference was observed for hs-CRP; median hs-CRP for those with severe obesity was 3-4 times higher than those with overweight or non-severe obesity, and exceeded the cutoff for elevated risk of CVD $(3.4 \mathrm{mg} / \mathrm{L})$. Participants with severe obesity also had a significantly greater median number of risk factors that remained after adjusting for age and gender (data not shown).

Subjects with severe obesity were more likely to report having sub-optimal health habits and health status when compared to those without $(27.5 \%$ vs. $12.5 \%$ vs. $11.1 \%$, respectively; $p=0.19$ and $62.5 \%$ vs. $37.9 \%$ vs. $35.3 \%$, respectively; $p=0.053$, Table 5$)$. They also reported higher median levels of stress ( 6.5 vs. 6.0 vs. 5.0 , respectively, $p=0.035$ ). Although most quality of life measures were lower in both the severely obese and obese, there were no statistically significant differences or consistent trends by weight category (Table 5). A posthoc subgroup analysis of the data from youth older than 13 years $(n=68)$, who completed the survey themselves as compared to youth 12 years and younger (where parents completed the survey, $n=37$ ) found that statistically significant differences in self-reported stress were seen in the older youth $(p=0.04)$, while in the younger children, lower scores were seen on social scale of PedsQL $(p=0.03)$ and approached significance in emotional scale $(p=0.05)$ and total score $(p=0.06)$.

\section{Discussion}

In this cross-sectional, clinic-based cohort of youth with overweight and obesity, there were expected increases in $\%$ total body fat with increasing classes of obesity. While the individuals with severe obesity were slightly older, the differences were not statistically significant. Similarly, youth with severe obesity had a higher prevalence of comorbidities including, asthma, OSA, depression, presence of multiple cardiometabolic risk factors, low HDLC, elevated HOMA-IR and elevated hs-CRP. Psychosocial and behavioral phenotypic differences were most compelling and possibly interrelated, including higher rates of emotional eating, eating when bored and perceived stress with increasing severity of obesity, and lower participation in organized sports as well as less maternal education. Understanding the underlying biology and interrelationships between these psychosocial and behavioral factors may help us to develop more effective prevention and treatment interventions to improve the health of youth with severe obesity.

The adverse levels of HDL-C, hs-CRP and HOMA-IR in individuals with severe obesity are consistent with the findings from other studies. Lower levels of HDL-C have been identified in youth with severe obesity from population-based NHANES data at younger ages prior to identifiable differences in other lipid parameters [5]. Elevated levels of hs-CRP associated with obesity in adults [21], and thought to herald the onset of cardiometabolic consequences, such as coronary heart disease [22], hypertension [23, 24], metabolic syndrome [25, 26] and diabetes [27] were significantly higher in the youth with severe obesity compared to those without. While such levels have been previously identified in adults, a similar association has not been well defined in children [21]. The presence of elevated hs-CRP and HOMA-IR in youth with severe obesity adds to the growing body of evidence that supports an urgent call for intervention to prevent the potential oncoming wave of cardiometabolic disease in the future generations.

Similar to other studies, there was a higher proportion of asthma, depression and obstructive sleep apnea in individuals with severe obesity. In a systematic review, Papoustakis et al noted the association of asthma in 30 out of the 31 cross-sectional studies and 12 out of the 13 prospective studies of individuals with obesity [28]. While the exact mechanism of this association remains to be elucidated, proposed mechanisms include systemic inflammation and mechanical effect, both due to expansion of the adipose tissue. There may also be a contribution of insulin resistance 
Table 3 Food intake and eating and activity behaviors according to weight category

\begin{tabular}{|c|c|c|c|c|c|}
\hline \multirow[t]{2}{*}{ Variable } & \multirow[t]{2}{*}{$n^{\mathrm{a}}$} & \multicolumn{3}{|c|}{ Weight Category } & \multirow[t]{2}{*}{$p$-value ${ }^{* *}$} \\
\hline & & Overweight & Obese & Severely Obese & \\
\hline \multicolumn{6}{|l|}{ Food intake and eating behaviors among all participants } \\
\hline \# servings per day Water, $n$ (\%) & 102 & & & & 0.31 \\
\hline $1-3$ /month to $1 /$ day & & $5(26.3 \%)$ & $5(16.7 \%)$ & $6(11.3 \%)$ & \\
\hline 2-3/day & & $3(15.8 \%)$ & $11(36.7 \%)$ & $14(26.4 \%)$ & \\
\hline More than 3/day & & $11(57.9 \%)$ & $14(46.7 \%)$ & $33(62.3 \%)$ & \\
\hline \# servings per day Regular Soda, $n(\%)$ & 100 & & & & 0.50 \\
\hline None & & $6(31.6 \%)$ & $10(34.5 \%)$ & $23(44.2 \%)$ & \\
\hline $1-3 /$ month to $1 /$ week & & $6(31.6 \%)$ & $11(37.9 \%)$ & $20(38.5 \%)$ & \\
\hline 2-4/week to more than 3/day & & $7(36.8 \%)$ & $8(27.6 \%)$ & $9(17.3 \%)$ & \\
\hline \# servings per day Diet Soda, $n(\%)$ & 102 & & & & 0.96 \\
\hline None & & $13(72.2 \%)$ & $19(63.3 \%)$ & $36(66.7 \%)$ & \\
\hline $1-3$ /month to $1 /$ week & & $4(22.2 \%)$ & $7(23.3 \%)$ & $12(22.2 \%)$ & \\
\hline 2-4/week to more than 3/day & & $1(5.6 \%)$ & $4(13.3 \%)$ & $6(11.1 \%)$ & \\
\hline \# servings per day Fruits, $n$ (\%) & 100 & & & & 0.13 \\
\hline None & & $3(16.7 \%)$ & $0(0 \%)$ & $1(2.0 \%)$ & \\
\hline $1-3 /$ month to $1 /$ week & & $3(16.7 \%)$ & $5(16.1 \%)$ & $8(15.7 \%)$ & \\
\hline 2-4/week to more than 3/day & & $12(66.7 \%)$ & $26(83.9 \%)$ & $42(82.4 \%)$ & \\
\hline \# servings per day Vegetables, $n(\%)$ & 103 & & & & 0.42 \\
\hline None & & $1(5.6 \%)$ & $1(3.2 \%)$ & $3(5.6 \%)$ & \\
\hline $1-3 /$ month to $1 /$ week & & $1(5.6 \%)$ & $8(25.8 \%)$ & $8(14.8 \%)$ & \\
\hline 2-4 /week to more than 3/day & & $16(88.9 \%)$ & $22(71.0 \%)$ & $43(79.6 \%)$ & \\
\hline \# days per week eat dinner at home; median (min, max) & 102 & $4.0(0,7.0)$ & 4. $0(0,7.0)$ & $3.0(0,7.0)$ & 0.06 \\
\hline \# days per week eat fast food; median (min, max) & 103 & $1.0(0,4.0)$ & $2.0(0,5.0)$ & $1.0(0,7.0)$ & 0.19 \\
\hline \# days per week eat breakfast; median (min, max) & 95 & $6.0(0,7.0)$ & $7.0(0,7.0)$ & $5.5(0,7.0)$ & 0.72 \\
\hline \multicolumn{6}{|l|}{$\begin{array}{l}\text { Eating behaviors among the subsample of adolescents } \\
13 \text { years and older }\end{array}$} \\
\hline Eat when bored or upset; $n(\%)$ & 69 & & & & 0.022 \\
\hline Never to less than once a month & & $13(100 \%)$ & $11(57.9 \%)$ & $18(48.6 \%)$ & \\
\hline 1 to 2 times a month & & $0(0 \%)$ & $4(21.1 \%)$ & $9(24.3 \%)$ & \\
\hline Once a week or more & & $0(0 \%)$ & $4(21.1 \%)$ & $10(27.0 \%)$ & \\
\hline Could not stop eating; $n$ (\%) & 69 & & & & 0.17 \\
\hline Never to less than once a month & & $13(100 \%)$ & $14(73.7 \%)$ & $26(70.3 \%)$ & \\
\hline $1-2$ times a month & & $0(0 \%)$ & $5(26.3 \%)$ & $9(24.3 \%)$ & \\
\hline Once a week or more & & $0(0 \%)$ & $0(0 \%)$ & $2(5.4 \%)$ & \\
\hline \multicolumn{6}{|l|}{$\begin{array}{l}\text { TFEQ-R18 Eating Behavior Scores (0-100); median } \\
\text { (min, max) }\end{array}$} \\
\hline Cognitive Restraint (CR) & 71 & $45.6(0,59.1)$ & $40.9(0,68.2)$ & $40.9(13.6,77.3)$ & 0.86 \\
\hline Uncontrolled Eating (UE) & 71 & $29.2(3.7,51.9)$ & $40.7(0,92.6)$ & $40.7(3.7,83.3)$ & 0.11 \\
\hline Emotional Eating (EE) & 70 & $11.1(0,66.7)$ & $16.7(0,100.0)$ & $33.3(0,100.0)$ & 0.026 \\
\hline \multicolumn{6}{|l|}{ Activity behaviors among all participants } \\
\hline $\begin{array}{l}\text { \# hours watching TV per day during weekdays; median } \\
\text { (min, max) }\end{array}$ & 103 & $3.0(1.0,6.0)$ & $3.0(1.0,7.0)$ & $3.0(1.0,7.0)$ & 0.18 \\
\hline $\begin{array}{l}\text { \# hours playing video games per day during weekdays; } \\
\text { median (min, max) }\end{array}$ & 101 & $3.0(1.0,7.0)$ & $3.0(1.0,7.0)$ & $3.0(1.0,7.0)$ & 0.59 \\
\hline \# days per week active for $\mathbf{3 0}+\mathbf{m i n s} /$ day; median & 103 & $3.0(1.0,7.0)$ & $3.0(0,7.0)$ & $3.0(0,7.0)$ & 0.90 \\
\hline
\end{tabular}


Table 3 Food intake and eating and activity behaviors according to weight category (Continued)

\begin{tabular}{|c|c|c|c|c|c|}
\hline \multirow[t]{2}{*}{ Variable } & \multirow[t]{2}{*}{$n^{\mathrm{a}}$} & \multicolumn{3}{|c|}{ Weight Category } & \multirow[t]{2}{*}{$p$-value ${ }^{* *}$} \\
\hline & & Overweight & Obese & Severely Obese & \\
\hline \multicolumn{6}{|l|}{$(\min , \max )$} \\
\hline \# organized sports teams/physical activities in the past year ; $n, \%$ & 103 & & & & 0.044 \\
\hline None & & $3(15.8 \%)$ & $11(35.5 \%)$ & $25(47.2 \%)$ & \\
\hline One & & $7(36.8 \%)$ & $9(29.0 \%)$ & 19 (35.8\%) & \\
\hline Two or more & & $9(47.4 \%)$ & 11 (35.5\%) & $9(17.0 \%)$ & \\
\hline
\end{tabular}

${ }^{a}$ number of participants after excluding missing or don't know/unknown responses for each variable

**P-values calculated from Fisher Exact Tests for categorical data or Jonckheere-Terpstra Test for Independent Samples for continuous data

and a role of intestinal microbial dysbiosis causing higher lipopolysaccharides or other inflammatory agents $[29,30]$. The association of depression with severe obesity has also been described, albeit without a clear directionality. One representative study of adolescents with obesity found that after adjusting for demographics and emotional eating, the odds of having severe obesity versus obesity were 3.5 times higher for patients with depression (as measured by PHQ9; a score $\geq 11$ was considered depression) compared with those without $(\mathrm{OR}=3.5,95 \%$ CI 1.2,20.9, $p=0.030)$ [31]. Similarly, the odds of having severe obesity were also higher with anxiety (Generalized Anxiety Disorder Scale $\geq 10, \mathrm{OR}=4.93,95 \% \mathrm{CI}=1.17,20.85, p=0.030$ ). In this study, there was no association of either depression or anxiety with emotional eating, but other studies have found emotional eating as a mediator for obesity in individuals with depression [32, 33]. A high level of psychosocial dysregulation along with problematic eating patterns and behaviors was noted by Gowen et al in their study of 54 young adults and adolescents [34]. Similarly, in a comparable group of adolescents prior to bariatric surgery, higher BMI, depressive symptoms and the number of medical comorbidities were significant predictors of the impaired weight related quality of life and closely related to dysregulated eating behaviors [35]. Differences in our findings that relate depression and anxiety to eating behaviors may be due to the use of different assessment strategies, as our study used medical diagnoses of depression or anxiety reported by the parent or adolescent/young adult rather than questionnaire measures that assess current depressive or anxiety symptoms. It is also postulated that the presence of depression elicits a response from the hypothalamic adrenal axis that leads to inflammatory milieu leading to obesity [36].

Notably, this study found that emotional eating and eating when bored were increased in individuals with severe obesity. A body of literature demonstrates the association of emotional dysregulation with weight gain and obesity [12, 31, 37, 38]. It has been suggested in adults that a poor emotional regulation may entail the use of maladaptive strategies to manage emotions and stress, for example, by using highly palatable and energy dense food to suppress emotions [39]. Studies in children have demonstrated that emotional eating is often followed by

Table 4 Metabolic risk factors overall and according to weight category

\begin{tabular}{|c|c|c|c|c|c|c|c|}
\hline \multirow[t]{2}{*}{ Characteristic $^{a}$} & \multirow[t]{2}{*}{$n^{\mathrm{b}}$} & \multirow{2}{*}{$\begin{array}{l}\% \\
\text { Exceed } \\
\text { Cutoff }\end{array}$} & \multirow[t]{2}{*}{ All } & \multicolumn{3}{|l|}{ Weight Category } & \multirow[b]{2}{*}{$p$-value ${ }^{* *}$} \\
\hline & & & & Overweight & Obese & Severely Obese & \\
\hline Triglycerides, mg/dL & 104 & $36.5 \%$ & $79.5(36.0,362.0)$ & $62.0(36.0,362.0)$ & $85.5(46.0,241.0)$ & $79.5(43.0,227.0)$ & 0.26 \\
\hline Total Chol, mg/dL & 104 & $43.3 \%$ & $164.0(118.0,237.0)$ & $160.5(122.0,237.0)$ & $173.0(124.00,228.0)$ & $163.0(118.0,231.0)$ & 0.73 \\
\hline HDL-Chol, mg/dL & 104 & $53.8 \%$ & $45.0(24.0,76.0)$ & $54.5(26.0,76.0)$ & $46.0(24.0,69.0)$ & $44.0(24.0,76.0)$ & 0.011 \\
\hline LDL- Chol, mg/dL & 104 & $41.3 \%$ & $96.0(21.0,155.0)$ & $88.0(47.0,154.0)$ & $100.0(21.0,155.0)$ & $96.5(43.0,151.0)$ & 0.40 \\
\hline $\mathrm{SBP}, \mathrm{mmHg}$ & 105 & $1.9 \%$ & $110.0(87.0,140.0)$ & $105.0(90.0,125.0)$ & $109.0(95.0,140.0)$ & $112.5(87.0,138.0)$ & 0.051 \\
\hline $\mathrm{DBP}, \mathrm{mmHg}$ & 105 & $1.0 \%$ & $67.0(43.5,85.0)$ & $63.0(57.0,81.0)$ & $67.0(43.5,85.0)$ & $68.0(47.5,81.0)$ & 0.59 \\
\hline CRP, mg/L & 104 & $28.8 \%$ & $1.63(0.10,70.41)$ & $0.97(0.10,3.85)$ & $0.77(0.18,70.41)$ & $3.40(0.19,38.16)$ & $<0.001$ \\
\hline HOMA-IR & 103 & $53.4 \%$ & $3.08(0.21,23.61)$ & $2.13(0.21,5.65)$ & $3.01(0.52,8.05)$ & $3.94(0.69,23.61)$ & $<0.001$ \\
\hline Insulin, ulU/mL & 103 & $63.1 \%$ & $16.0(1.4,102.8)$ & $10.6(1.4,26.3)$ & $11.6(2.8,35.2)$ & $20.05(3.8,102.8)$ & $<0.001$ \\
\hline Glucose, mg/dL & 104 & $2.9 \%$ & $80.0(62.0,255.0)$ & $80.5(62.0,120.0)$ & $82.0(70.0,97.0)$ & $79.0(63.0,255.0)$ & 0.54 \\
\hline \# of risk factors & 103 & & $2(0,5)$ & $1(0,3)$ & $1(0,4)$ & $2(0,5)$ & 0.003 \\
\hline
\end{tabular}

${ }^{a}$ Median (Minimum, Maximum) values for each risk factor

${ }^{b}$ number of participants with non-missing data

**P-values calculated from Jonckheere-Terpstra Test for Independent Samples 
Table 5 Health related attitudes and perceptions

\begin{tabular}{|c|c|c|c|c|c|}
\hline Variable & $n^{\mathrm{a}}$ & Overweight & Obese & Severely Obese & $p$-value** \\
\hline \multicolumn{6}{|l|}{ General Health } \\
\hline Health in General; n (\%) & 100 & & & & 0.19 \\
\hline Fair/Poor & & $2(11.1 \%)$ & $4(12.5 \%)$ & $14(27.5 \%)$ & \\
\hline Good/Very good/Excellent & & $16(88.9 \%)$ & 27 (87.1\%) & 37 (72.5\%) & \\
\hline Health Habits; $n$ (\%) & 94 & & & & 0.05 \\
\hline Fair/Poor & & $6(35.3 \%)$ & $11(37.9 \%)$ & $30(62.5 \%)$ & \\
\hline Good/Very good/Excellent & & $11(64.7 \%)$ & $18(62.1 \%)$ & $18(37.5 \%)$ & \\
\hline Perceived Stress [1-10] & 94 & $5.0(1.0,9.0)$ & $6.0(2.0,10.0)$ & $6.5(2.0,10.0)$ & 0.01 \\
\hline \multicolumn{6}{|l|}{$\begin{array}{l}\text { Quality of Life Scores (0-100); } \\
\text { median (min, max) }\end{array}$} \\
\hline Overall & 100 & $81.5(48.9,95.7)$ & $75.0(36.4,100.0)$ & $75.0(32.6,100.0)$ & 0.11 \\
\hline Physical Health & 102 & $87.5(21.9,100.0)$ & $78.1(34.4,100.0)$ & $78.1(37.5,100.0)$ & 0.15 \\
\hline Psychosocial Health & 100 & $80.8(53.3,95.0)$ & $70.0(37.5,100.0)$ & $70.0(26.7,100.0)$ & 0.15 \\
\hline School Functioning & 101 & $80.0(45.0,95.0)$ & $65.0(30.0,100.0)$ & $65.0(25.0,100.0)$ & 0.26 \\
\hline Emotional Functioning & 101 & $77.5(45.0,100.0)$ & $70.0(25.0,100.0)$ & $65.0(25.0,100.0)$ & 0.26 \\
\hline Social Functioning & 100 & $85.0(45.0,100.0)$ & $90.0(35.0,100.0)$ & $80.0(30.0,100.0)$ & 0.16 \\
\hline
\end{tabular}

${ }^{a}$ number of participants after excluding missing or don't know/unknown responses for each variable

**P-values calculated from Fisher Exact Tests for categorical data or Jonckheere-Terpstra Test for Independent Samples for continuous data

negative emotions [40-43], and is likely to be a learned behavior $[44,45]$. College students identified boredom as the emotion that most commonly triggers eating [46], a finding that was replicated in the laboratory where the completion of a boring task was associated with snacking desire [47]. Assessment of subtypes of emotional eating in a cohort of 189 adults showed eating in response to depression (EE-D), anxiety/anger (EE-A) and boredom (EE-B) related to poorer psychological well-being, greater symptoms of eating disorder and more difficulties with emotional regulation [48]. It is also possible that the association of depression and severe obesity is mediated by emotional eating as demonstrated in college students in Mexico City [32] and Netherlands [33]. Findings highlight the importance of building skills for emotional regulation for children and adolescents with severe obesity [49]. Findings for emotional eating could also be explained by experiences of weight stigma (e.g. weight related teasing) that are more likely to be experienced by youth with severe obesity [50].

This study highlights the role of stress experienced by youth with obesity, especially in the older age group, that is increasingly being recognized to have a complex, perhaps bidirectional, relationship [51]. Studies of hair cortisol concentration, thought to be deposited over longer periods of time, both in adults $[52,53]$ and in children [54] have been shown to have high associations with obesity. Whether this relationship is linked to biological factors such as higher levels of circulating glucocorticoids or higher response to circulating glucocorticoids that predispose individuals to weight gain, or changes in internal milieu, such as imbalances in glucose homeostasis, is not clear. On the other hand, the higher levels of weight stigma carried by individuals with obesity, mental health issues (e.g. depression, anxiety etc), or physical disorders (e.g. asthma, OSA) can lead to chronic stress and/or higher circulating corticosteroids, making it a vicious cycle. The presence of higher levels of comorbidities that can lead to increased levels of biological stress as well as the higher perceived levels of stress in this study, emphasize the role of both recognition and management of stress in youth with obesity. The differences in the PEDS-QL in children with severe obesity, as have been noted in prior studies of children with obesity [55] were more prominent in the younger age group in this study, perhaps indicating that older children and adolescents may perceive the psychosocial pressures induced by obesity as stress.

Participants with severe obesity exhibited a reduced number of organized physical activities. It is not known whether the inactivity preceded the severe obesity or is a consequence of potential reduction in the agility of the body by excessive weight. However, there is evidence in the literature that lack of physical activity may be linked to the state of emotional dysregulation known to be associated with obesity $[8,48]$. Emerging evidence emphasizing the positive role of team sport participation on longer term mental health, especially in children who have experienced adverse childhood events [56] makes this an important consideration in youth such as those in this study. This study found no statistically significant differences in the dietary intake of foods shown to be 
related to risk of obesity including the servings of water, sugar sweetened beverages, fruits and vegetables, as well as the patterns of meals eaten at home and fast food intake. The lack of differences may be due to the source of the sample, as participants were attending weight management programs and following treatment recommendations provided those programs.

This study is limited by its cross-sectional design as well as recruitment in tertiary care weight management programs that may limit the generalizability of some of the findings. While a thorough assessment of body composition and cardiometabolic risk factors was done, the measurement of dietary intake was limited to selfreported frequency of selected food groups and physical activities. Parent report on surveys for younger children limits our ability to discern the extent to which this represents children's perceptions on various measures such as quality of life and stress. Further, the small sample size limits the comparison across gender and race/ethnicity groups. However, the comprehensive assessment in the study has provided the opportunity to identify important psychosocial, behavioral and clinical correlates that may play a role in the more effective management of obesity in such a population.

This study is one of the few studies that have tried to comprehensively characterize differences in physiological, psychosocial and behavioral phenotypes in adolescents with severe obesity. The higher prevalence of psychological and behavioral phenotypes in this sample suggests that there are modifiable and possibly related targets of intervention. It also re-emphasizes the need for a multidisciplinary team including clinician, behavioral psychologist, social worker and exercise physiologist to identify and address multitude of complex problems in these patients. Future larger and longitudinal studies are needed to tease out the causal pathways and interactions between these important modifiable targets of intervention.

\section{Conclusions}

Higher rates of co-morbidity were seen in youth with severe obesity compared to those without. Youth with severe obesity also had higher proportion of psycho-social and behavioral phenotypes including higher rates of emotional eating, eating when bored and perceived stress. Whether these are the causes or the results of severe obesity in youth needs to be explored further for better care of this growing population.

\footnotetext{
Abbreviations

POOL registry: Registry with patients enrolled from the PREP clinic, Optimal Weight for Life program, One Step Ahead program and Lipid clinic, Boston Children's Hospital; BMI: Body Mass Index; HOMA-IR: Homeostatic Model Assessment of Insulin Resistance; hs-CRP: High sensitivity C-reactive protein; NHANES: National Health and Nutrition Examination Survey; CDC: Centers for Disease Control; ADHD: Attention Deficit Hyperactivity Disorder; HDL-C: Highdensity Lipoprotein Cholesterol; LDL-C: Low-density Lipoprotein Cholesterol;
}

VLDL-C: Very low-density Lipoprotein Cholesterol; TG: Triglyceride; CV: Coefficient of variation; CVD: Cardiovascular disease; PHQ-9: Patient Health Questionnaire - 9; OSA: Obstructive Sleep Apnea

\author{
Acknowledgements \\ none. \\ Disclosure summary \\ The opinions and assertions expressed herein are those of the authors and \\ are not to be construed as reflecting the views of the National Institutes of \\ Health, or the US Department of Health and Human Services.
}

\section{Authors' contributions \\ SKO and TKR designed the study and the acquisition of the patient materials. SDdeF and KRS contributed to the study design and patient recruitment. JKC and WT participated in patient recruitment and data acquisition. HAF and SKO analyzed the data. All authors have read and approved the manuscript as submitted.}

\section{Funding}

The POOL registry was funded in part by Milton Fund, New Balance Foundation Obesity Prevention Center, and Boston Children's Hospital for the resources required to enroll participants and conduct sample collection and laboratory studies. WT is partly supported for research career development by NIH-NIDDK K23 DK 110539.

\section{Availability of data and materials}

The datasets generated and/or analyzed during the current study are not publicly available due to IRB restrictions for sharing individual level data but are available from the corresponding author on reasonable request.

\section{Ethics approval and consent to participate}

This study was approved by the Institutional Review Board at Boston Children's Hospital. Written informed consent was obtained from a parent or legal guardian for minors $<18$ years or from adult participants and a written assent from youth ages $8-17$ years.

\section{Consent for publication}

Not applicable.

\section{Competing interests \\ none.}

\section{Author details}

${ }^{1}$ Division of Molecular Genetics, Department of Pediatrics, Columbia University Irving Medical Center, 1150, St. Nicholas Avenue, New York, NY 10032, USA. ${ }^{2}$ National Institute of Diabetes and Digestive and Kidney Diseases, National Institutes of Health, Bethesda, MD 20892, USA. ${ }^{3}$ Division of Ambulatory Cardiology, Deparment of Cardiology, Boston Children's Hospital, Boston, MA 02115, USA. ${ }^{4}$ Department of Pediatrics, Harvard Medical School, Boston, MA 02115, USA. ${ }^{5}$ University of Michigan School of Public Health, Ann Arbor, Ml 48109, USA. ${ }^{6}$ Division of Primary Care, Boston Children's Hospital, Boston, MA 02115, USA. 'Institutional Centers for Clinical and Translational Research, Boston Children's Hospital, Boston, MA 02115, USA. ${ }^{8}$ Division of Adolescent/Young Adult Medicine, Boston Children's Hospital, Boston, MA 02115, USA.

Received: 2 July 2019 Accepted: 14 May 2020

Published online: 10 June 2020

\section{References}

1. Hales CM, Fryar CD, Carroll MD, Freedman DS, Ogden CL. Trends in obesity and severe obesity prevalence in US youth and adults by sex and age, 2007-2008 to 2015-2016. JAMA J Am Med Assoc. 2018;319(16):1723-5. https://doi.org/10.1001/jama.2018.3060.

2. Skinner AC, Ravanbakht SN, Skelton JA, Perrin EM, Armstrong SC. Prevalence of obesity and severe obesity in US children, 1999-2016. Pediatrics. 2018; 141(3):e20173459. https://doi.org/10.1542/peds.2017-3459.

3. Ogden CL, Fryar CD, Hales CM, Carroll MD, Aoki Y, Freedman DS. Differences in obesity prevalence by demographics and urbanization in US 
children and adolescents, 2013-2016. JAMA - J Am Med Assoc. 2018;319(23): 2410-8. https://doi.org/10.1001/jama.2018.5158.

4. Kelly AS, Barlow SE, Rao G, et al. Severe obesity in children and adolescents: identification, associated health risks, and treatment approaches: a scientific statement from the American Heart Association. Circulation. 2013;128(15): 1689-712.

5. Skinner AC, Perrin EM, Moss LA, Skelton JA. Cardiometabolic risks and severity of obesity in children and young adults. N Engl J Med. 2015;373(14): 1307-17. https://doi.org/10.1056/NEJMoa1502821.

6. Zabarsky G, Beek C, Hagman E, Pierpont B, Caprio S, Weiss R. Impact of severe obesity on cardiovascular risk factors in youth. J Pediatr. 2018;192: 105-14. https://doi.org/10.1016/j.jpeds.2017.09.066.

7. Barros R, Moreira P, Padrao P, Teixeira VH, Carvalho P, Delgado L. Obesity increases the prevalence and the incidence of asthma and worsens asthma severity. Clin Nutr. 2017;36:1068-74. https://doi.org/10. 1016/j.clnu.2016.06.023.

8. Dreber H, Reynisdottir S, Angelin B, Tynelius P, Rasmussen F, Hemmingsson E. Mental distress in treatment seeking young adults (18-25 years) with severe obesity compared with population controls of different body mass index levels: cohort study. Clin Obes. 2017;7(1):1-10. https://doi.org/10.1111/ cob.12170.

9. Kamath CC, Vickers KS, Ehrlich A, et al. Behavioral interventions to prevent childhood obesity: a systematic review and metaanalyses of randomized trials. J Clin Endocrinol Metab. 2008;93(12):4606-15. https://doi.org/10.1210/ jc.2006-2411.

10. JaKa MM, French SA, Wolfson J, et al. Understanding outcomes in behavior change interventions to prevent pediatric obesity: the role of dose and behavior change techniques. Heal Educ Behav. 2019;46(2):312-21. https:// doi.org/10.1177/1090198118798679.

11. Fox CK, Gross AC, Bomberg EM, et al. Severe obesity in the pediatric population: current concepts in clinical care. Curr Obes Rep. May 2019. https://doi.org/10.1007/s13679-019-00347-z.

12. Gross AC, Fox CK, Rudser KD, Foy AMHH, Kelly AS. Eating behaviours are different in youth with obesity and severe obesity. Clin Obes. 2016;6(1):6872. https://doi.org/10.1111/cob.12127.

13. Elberg J, Mcduffie JR, Sebring NG, et al. Comparison of methods to assess change in children 's body. Clin Res. 2004:64-9.

14. Ginde SR, Geliebter A, Rubiano F, et al. Air displacement plethysmography: validation in overweight and obese subjects. Obes Res. 2005;13(7):1232-7. https://doi.org/10.1038/oby.2005.146.

15. Tanner JM. Normal growth and techniques of growth assessment. Clin Endocrinol Metab. 1986;15(3):411-51. https://doi.org/10.1016/S0300595X(86)80005-6.

16. Troped PJ, Wiecha JL, Fragala MS, et al. Reliability and validity of YRBS physical activity items among middle school students. Med Sci Sports Exerc. 2007;39(3):416-25. https://doi.org/10.1249/mss.0b013e31802d97af.

17. Varni JW, Seid M, Kurtin PS. and Validity of the Pediatric Quality of PedsQLTM Version 4 . 0 Generic Core Scales in Healthy Life InventoryTM and Patient Populations. Med Care. 2001;39(8):800-12.

18. Varni JW, Limbers CA. The pediatric quality of life inventory: measuring pediatric health-related quality of life from the perspective of children and their parents. 2009;56:843-63. https://doi.org/10.1016/j.pcl.2009.05.016.

19. Karlsson J, Persson L-O, Sjöström L, Sullivan M. Psychometric properties and factor structure of the Three-Factor Eating Questionnaire ( TFEQ ) in obese men and women. Results from the Swedish Obese Subjects ( SOS ) study. Int J Obes. 2000;24:1715-25.

20. Shisslak CM, Renger R, Sharpe T, et al. Development and evaluation of the McKnight risk factor survey for assessing potential risk and protective factors for disordered eating in preadolescent and adolescent girls. Int J Eat Disord. 1999;25(2):195-214. https://doi.org/10.1002/(SICI) 1098-108X(199903)25:2< 195::AID-EAT9>3.0.CO;2-B.

21. Choi J, Joseph L, Pilote L. Obesity and C-reactive protein in various populations: a systematic review and meta-analysis. Obes Rev. 2013;14(3): 232-44. https://doi.org/10.1111/obr.12003.

22. Danesh J, Wheeler JG, Hirschfield GM, et al. C-reactive protein and other circulating markers of inflammation in the prediction of coronary heart disease. N Engl J Med. 2004;350(14):1387-97. https://doi.org/10.1056/ NEJMoa032804.

23. Cifkova R, Frohlich J, Skodova Z, et al. C-Reactive Protein and the Risk of Developing Hypertension. a Population Study. J Hypertens. 2004;22(Suppl. 2):S149. https://doi.org/10.1097/00004872-200406002-00510.
24. Sesso HD, Buring JE, Rifai N, Blake GJ, Gaziano JM, Ridker PM. C-reactive protein and the risk of developing hypertension. JAMA J Am Med Assoc. 2003;290(22):2945-51. https://doi.org/10.1001/jama.290.22.2945.

25. Pearson TA, Mensah GA, Alexander RW, et al. Markers of inflammation and cardiovascular disease: application to clinical and public health practice: a statement for healthcare professionals from the centers for disease control and prevention and the American Heart Association. Circulation. 2003, 107(3):499-511. https://doi.org/10.1161/01.CIR.0000052939.59093.45.

26. Kahn SE, Zinman B, Haffner SM, et al. Obesity is a major determinant of the association of C-reactive protein levels and the metabolic syndrome in type 2 diabetes. Diabetes. 2006;55(8):2357-64. https://doi.org/10.2337/db06-0116.

27. Han TS, Sattar N, Williams K, Gonzalez-Villalpando C, Lean MEHS. Prospective study of C-reactive protein in relation to the development of diabetes and metabolic syndrome in the Mexico City diabetes study. Diabetes Care. 2002; 25(11):2016-21.

28. Papoutsakis C, Priftis KN, Drakouli M, et al. Childhood overweight/obesity and asthma: is there a link? A systematic review of recent epidemiologic evidence. J Acad Nutr Diet. 2013;113(1):77-105. https://doi.org/10.1016/j. jand.2012.08.025.

29. Gomez-Llorente MA, Romero R, Chueca N, Martinez-Cañavate A, GomezLlorente C. Obesity and asthma: a missing link. Int J Mol Sci. 2017;18(7):1-12. https://doi.org/10.3390/ijms18071490.

30. Kelsey MM, Zaepfel A, Bjornstad P, Nadeau KJ. Age-related consequences of childhood obesity. Gerontology. 2014;60(3):222-8. https://doi.org/10.1159/ 000356023.

31. Fox CK, Gross AC, Rudser KD, Foy AMH, Kelly AS. Depression, anxiety, and severity of obesity in adolescents: is emotional eating the link? Clin Pediatr (Phila). 2016;55(12):1120-5. https://doi.org/10.1177/0009922815615825.

32. Lazarevich I, Esther M, Camacho I, Del M, Vel Azquez-Alva C, Zepeda M. Relationship among obesity, depression, and emotional eating in young adults. Appetite. 2016;107:639-44. https://doi.org/10.1016/j.appet.2016.09.011.

33. Antoniou EE, Bongers $\mathrm{P}$, Jansen $\mathrm{A}$. The mediating role of dichotomous thinking and emotional eating in the relationship between depression and BMI. Eat Behav. 2017;26:55-60. https://doi.org/10.1016/j.eatbeh.2017.01.007.

34. Gowey MA, Reiter-purtill J, Becnel J, Mitchell JE, Zeller MH. Sciences H. HHS Public Access. 2017:211-8. https://doi.org/10.1016/.appet.2016.01.020. Weight-Related.

35. Zeller MH, Inge TH, Modi AC, et al. Severe Obesity and Comorbid Condition Impact on the Weight-Related Quality of Life of the Adolescent Patient. J Pediatr. 2014;166(3):651-9.e4. https://doi.org/10.1016/j.jpeds.2014.11.022.

36. Kiecolt-Glaser JK, Fagundes CP, Andridge R, et al. Depression, daily stressors and inflammatory responses to high-fat meals: when stress overrides healthier food choices. Mol Psychiatry. 2017;22(3):476-82. https://doi.org/10. 1038/mp.2016.149.

37. Powell EM, Frankel LA, Hernandez DC. The mediating role of child selfregulation of eating in the relationship between parental use of food as a reward and child emotional overeating. Appetite. 2017;113:78-83. https:// doi.org/10.1016/j.appet.2017.02.017.

38. Aparicio E, Canals J, Arija V, De Henauw S, Michels N. The role of emotion regulation in childhood obesity: implications for prevention and treatment. Nutr Res Rev. 2016;29(01):17-29. https://doi.org/10.1017/ S0954422415000153.

39. Taut $D$, Renner B, Baban A. Reappraise the situation but express your emotions: impact of emotion regulation strategies on ad libitum food intake. Front Psychol. 2012;3:359. https://doi.org/10.3389/fpsyg.2012.00359.

40. Goossens L, Braet C, Van Vlierberghe L, Mels S. Loss of control over eating in overweight youngsters: the role of anxiety, depression and emotional eating. Eur Eat Disord Rev. 2009;17(1):68-78. https://doi.org/10.1002/erv.892.

41. Michels N, Sioen I, Braet C, et al. Stress, emotional eating behaviour and dietary patterns in children. Appetite. 2012;59(3):762-9. https://doi.org/10. 1016/j.appet.2012.08.010.

42. Jääskeläinen $\mathrm{A}$, Nevanperä $\mathrm{N}$, Remes J, Rahkonen $\mathrm{F}$, Järvelin $\mathrm{MR}$, Laitinen J. Stress-related eating, obesity and associated behavioural traits in adolescents: a prospective population-based cohort study. BMC Public Health. 2014;14(1):321. https://doi.org/10.1186/1471-2458-14-321.

43. Power TG, Olivera YA, Hill RA, et al. Emotion regulation strategies and childhood obesity in high risk preschoolers. Appetite. 2016;107:623-7. https://doi.org/10.1016/j.appet.2016.09.008.

44. Herle M, Fildes A, Steinsbekk S, Rijsdijk F, Llewellyn CH. Emotional over- and under-eating in early childhood are learned not inherited. Sci Rep. 2017;7(1): 9092. https://doi.org/10.1038/s41598-017-09519-0. 
45. Herle $\mathrm{M}$, Fildes $\mathrm{A}$, Llewellyn $\mathrm{CH}$. Emotional eating is learned not inherited in children, regardless of obesity risk. Pediatr Obes. 2018;13(10):628-31. https:// doi.org/10.1111/ijpo.12428.

46. Koball AM, Meers MR, Storfer-Isser A, Domoff SE, Musher-Eizenman DR. Eating when bored: revision of the emotional eating scale with a focus on boredom. Health Psychol. 2012;31(4):521-4. https://doi.org/10.1037/ a0025893.

47. Moynihan AB, van Tilburg WAP, Igou ER, Wisman A, Donnelly AE, Mulcaire JB. Eaten up by boredom: Consuming food to escape awareness of the bored self. Front Psychol. 2015;6(APR):1-10. https://doi.org/10.3389/fpsyg. 2015.00369.

48. Braden A, Musher-Eizenman D, Watford T, Emley E. Eating when depressed, anxious, bored, or happy: are emotional eating types associated with unique psychological and physical health correlates? Appetite. 2018;125: 410-7. https://doi.org/10.1016/i.appet.2018.02.022.

49. Boutelle KN, Braden A, Knatz-Peck S, Anderson LK, Rhee KE. An open trial targeting emotional eating among adolescents with overweight or obesity. Eat Disord. 2018;26(1):79-91. https://doi.org/10.1080/10640266.2018.1418252.

50. Olvera N, Dempsey A, Gonzalez E, Abrahamson C. Weight-related teasing, emotional eating, and weight control behaviors in Hispanic and African American girls. Eat Behav. 2013;14(4):513-7. https://doi.org/10.1016/j.eatbeh. 2013.06.012.

51. van der Valk ES, Savas M, van Rossum EFC. Stress and obesity: are there more susceptible individuals? Curr Obes Rep. 2018;7(2):193-203. https://doi. org/10.1007/s13679-018-0306-y.

52. Stalder T, Steudte-Schmiedgen S, Alexander N, et al. Stress-related and basic determinants of hair cortisol in humans: a meta-analysis. Psychoneuroendocrinology. 2017;77:261-74. https://doi.org/10.1016/j. psyneuen.2016.12.017.

53. Wester VL, Staufenbiel SM, Veldhorst MAB, et al. Long-term cortisol levels measured in scalp hair of obese patients. Obesity. 2014;22(9):1956-8. https:// doi.org/10.1002/oby.20795.

54. Noppe G, Van Den Akker ELT, De Rijke YB, Koper JW, Jaddoe WW, Van Rossum EFC. Long-term glucocorticoid concentrations as a risk factor for childhood obesity and adverse body-fat distribution. Int J Obes. 2016;40(10): 1503-9. https://doi.org/10.1038/ijo.2016.113.

55. Griffiths $L J$, Parsons TJ, Hill AJ. Self-esteem and quality of life in obese children and adolescents: a systematic review. Int J Pediatr Obes. 2010;5(4): 282-304. https://doi.org/10.3109/17477160903473697.

56. Easterlin MC, Chung PJ, Leng M, Dudovitz R. Association of Team Sports Participation with Long-term Mental Health Outcomes among Individuals Exposed to adverse childhood experiences. JAMA Pediatr. May 2019. https://doi.org/10.1001/jamapediatrics.2019.1212.

\section{Publisher's Note}

Springer Nature remains neutral with regard to jurisdictional claims in published maps and institutional affiliations.

Ready to submit your research? Choose BMC and benefit from:

- fast, convenient online submission

- thorough peer review by experienced researchers in your field

- rapid publication on acceptance

- support for research data, including large and complex data types

- gold Open Access which fosters wider collaboration and increased citations

- maximum visibility for your research: over $100 \mathrm{M}$ website views per year

At $\mathrm{BMC}$, research is always in progress.

Learn more biomedcentral.com/submissions 